\title{
TECHNICAL PROBLEMS OF MAKING MODEL BY PARAMETRIC METHODS FOR SUPPORT AUTHORING TOOLS
}

\author{
Josef MAŤ̌JUS, Josef $\breve{S E D I V Y ́ ~}$
}

\begin{abstract}
The report deals with possibilities of various information technologies integration into the thechnologically aimed subjects. Presently computer support of designing is inseparable part of technological subjects teaching. Study hours and assumption of parametric modelling technics can be made easy by the multimedia device usage.
\end{abstract}

Key words: parametric modeling, multimedia support for teaching computer graphics, multimedia support teaching, virtual learning.

\section{PROBLEMATIKA TVORBY TECHNICKÉHO MODELU PARAMETRICKÝMI METODAMI ZA PODPORY AUTORSKÝCH NÁSTROJÜ}

Resumé: V současné době se programy pro technické modelováni využivají téměr ve všech oblastech. Setkáváme se s nimi jak v technické praxi, tak v běžném životě a to $i$ v oblastech, kde se nám to zdálo dřve na prvni pohled téměr nemyslitelné. Nahrazuje to $v$ podstatě fantazii a představivost konstruktéra a v mnoha prípadech pomáhá určit $i$ kolizni situace a body př́ vytvářeni nových produktù. Jelikož v současné době jsou již tyto programy cenově dostupnějšì, tak počitačová grafika nacházi mnohé využití $i$ v praktické školní výuce, a to jak prímo při vyučování, tak i pro prípravu studijních materiálů.

Klíčová slova: parametrické modelováni, multimediálni podpora výuky, počítačová grafika, multimediálni opora výuky, virtuální výuka.

\section{1 Úvod}

Do výuky technických předmětů $\mathrm{v}$ současné době nevyhnutelně zasahuje počítačová podpora navrhování. Jádrem každého CA/D (computer aided design) systému je parametrický modelár. Současným trendem $\mathrm{v}$ procesu navrhování předmětů nejen technické povahy je aplikování parametrického modelování, které přináší určitou vyjadřovacích prostředků. $\mathrm{S}$ využitím pokročilých technologií počítačové grafiky lze realizovat i obtížné fáze návrhu tělesa při současném zobrazení jeho reálné podoby. Efektivita parametrického modelování vyplývá z jeho filozofie. Popis modelu např. technické součásti prostřednictvím parametrů a matematických výrazů umožňuje jeho bezprostřední modifikaci, dále pak automatické promítnutí takové modifikace do sestav, výkresové dokumentace či navazujících nástrojů kontroly a výroby. Tím dochází $\mathrm{k}$ redukování výrobních nákladů již ve fázi návrhu budoucího výrobku.

\section{Začlenění parametrického modelování do} výuky

Parametrické modeláře se mohou lišit svým prostředím, uživatelským rozhraním, obecné principy parametrického modelování však zůstávají obdobnými. Př́islušná softwarová aplikace plní zejména funkci tvořivého nástroje. Modely jsou tvořeny prostřednictvím náčrtù a objemových či plošných konstrukčních prvků. Jejich definice musejí být jednoznačné bez redundantních či rozporuplných informací, možných řešení vždy existuje více. Na studenty jsou kladeny značné nároky $\mathrm{v}$ oblastech logického myšlení a prostorové představivosti. V uvedeném spočívá řada príležitostí pro aplikování alternativních metod výuky, problémového i projektového vyučování, rozvoj tvořivé i týmové práce. Učení se řešení problémů dle Linharta (1967) spočívá v tom, že si student osvojuje schopnost samostatně vyhledávat postupy a strategie řešení a rozhodovat se $\mathrm{v}$ alternativních situacích.

\section{Realizace multimediálních opor výuky parametrického modelování}

Pokrok informačních technologií přináší určité změny forem i metod vzdělávání. Aplikování multimediálních opor umožňuje zkvalitnění vyučovacího procesu. Například grafické symboly reprezentující vazby náčrtů nebo hodnoty parametrických kót jsou poměrně 
malé a zpravidla je nelze společně s ostatními entitami pracovní plochy zvětšovat. Pro názorný popis práce a zobrazení jednotlivých detailů je tedy základním předpokladem záznam obrazu ve vysokém rozlišení. Aplikování on-line technologií je vzhledem ke značným datovým tokům limitováno parametry sít'ového připojení. Současný životní styl si vyžaduje především rychlost a názornost. $\mathrm{Z}$ tohoto hlediska jsou velmi výhodné různé nástroje pro vzdělávací postupy využívající demonstračnía názorné př́klady. Právě proto se vytvářejí softwary, které používají interaktivní prostředí, která simulují práci s reálným programem (např̀. produkty Microsoft Office - Word, Excel, PowerPoint, Access a další). Programů pro tuto tvorbu je nespočet. Hlavní firmou pro vývoj těchto aplikací je renomovaná firma Adobe (přesný název Adobe Systems Incorporated). Jejich programy Captivate, Director, Authorware, Robohelp aj. mají jednu společnou velkou nevýhodu - jsou placené. Navíc jsou jejich ceny poměrně značně vysoké, protože jsou určeny hlavně pro firmy. $\mathrm{Na}$ druhou stranu jsou ovšem pro své neocenitelné vlastnosti na poli interaktivní multimediální výuky skutečnou špičkou. Ovšem v oblasti interaktivní multimediální výuky se vyskytují i programy poskytované zdarma. Nejdůležitějším př́kladem takového programu je velmi hodnotný program Wink. Všechny softwary pak nabízejí konečnou konverzi formátů do výsledných produktů. Aplikace od Adobe mohou vytvářet multimediální prezentace, mnou požadované postupy a manuály využívající Flash, jako jsou zejména animace, interaktivita, zvukový a obrazový doprovod. Samozřejmě, že následná tvorba je velmi náročná na čas pro jednotlivce, který navíc administruje běžnou výuku na univerzitě. Čím je výsledná práce rozsáhlejší, tím jsou vyšší také hardwarové nároky. To přináší další finanční zátěž pro pracoviště a učebny, které moderní metody aplikují Autor musí zvládnout zpracování více typů činností najednou, než tomu bývá u běžných programů. Během tvorby prezentací se stává autor grafikem, animátorem, střihačem filmů, atd. Sledovat tento vývoj a účastnit se nespočetných školení je pro univerzitního učitele fyzicky a psychicky nemožné. Běžnou metodou př́pravy výukových prezentací a multimediálních aplikací je spolupráce více lidí v pracovním týmu. Dokonce díky integrovaným funkčním průvodcovským modulům je $\mathrm{v}$ elementárnější podobě př́stupná $\mathrm{i}$ pro práci běžného samostatného uživatele. Programů zabývajících se touto tematikou je několik. Existují základní a známé aplikace pro tvorbu instruktážních prezentací a obsahů webových stránek, nekomerční programy napomáhající základním a rychlým způsobům výroby didaktických sdělení (Microsoft Office PowerPoint, Publisher, Adobe Flash Professional, Replay Screencast, RoboDemo, CamStudioa mnoho dalších). Multimediální aplikace dnes ovšem znamená jistou míru profesionality a specializace. Př́iklady výčtu aplikací pro tvorbu interaktivních multimediálních prezentací o kterých by měl mít učitel přehled jsou zejména :Wink, Camtasia Studio,Adobe Director, Adobe Authorware,, Adobe RoboHelp,Adobe Captivate.

\section{Jednoduchý a efektivní prríklad tvorby multimediálních opor}

Ne všechny nástroje vyžadují profesionální znalosti úměrné výsledku. Jako príklad velmi efektivního prostředí pro tvorbu multimediálních opor bez nutnosti rozsáhlých školení a studia uvedeme prostředí Captivate. Internetové stránky serveru Digitalmedia (součást serveru Adobe) popisují práci s programem Captivate Principiálně pouhé tři kroky stačí $\mathrm{k}$ tomu, aby byl pomocí Captivate vytvořena efektní instruktážní prezentace nebo simulace práce ve vybraném programu. Captivate automaticky ukládá všechny akce, které $\mathrm{v}$ nahrávacím režimu na obrazovce provedete.Vysokorychlostní počítačové sítě umožňují kontinuální přenosy videa o vysokém rozlišení streamováním mezi zdrojem a koncovým uživatelem. Další alternativou je přenos prostřednictvím systému „video on demand“. Digitální technologie umožňují i reprodukci audiovizuálního záznamu uloženého na optickém disku prostřednictvím počítače nebo televizoru a přehrávače, jejich uplatnění je tedy široké. Přenos např. obrazu multimediálního disku (zpravidla datový formát ISO) mezi klientem a FTP serverem je také možný, což je výhodné např. pro studenty distančního studia.

Vlastní audiovizuální záznam lze realizovat prostřednictvím videokamer a dalších nezbytných technických prostředků. Alternativním řešením je využití systému pro záznam a zpř́stupnění přednášek, napřr. Sonic Foundry Mediasite. Takový systém je však vhodnější pro záznam př̀ednášek,při kterých jsou prostřednictvím počítače prezentovány statické obrazové materiály. Pro záznam přednášek s využitím animací nebo videosekvencí či vystoupení, která obsahují demonstraci počítačového softwaru, je dle Sedláčka (2007) výhodné aplikování jiných technologií. Správné osvětlení osoby 
přednášejícího je nezbytné pro záznam jeho obrazu, může však negativně ovlivnit kvalitu současně probíhající obrazové prezentace. Pro vizuální popis práce $\mathrm{v}$ parametrickém modeláŕi však není relevantním záznam obrazu přednášejícího, ale zejména záznam obrazu pracovní plochy počítače. Zpravidla záleží na každém správném tahu kurzorem. Nejisté pohyby kurzoru či príípadné prohledávání nabídek softwarové aplikace $\mathrm{v}$ rámci přednášky je pro studenty matoucí. Stejně působí i používání klávesových zkratek, které není v pracovní ploše počítače vizuálně patrné. Pouze některé systémy pro zachycení obrazu pracovní plochy počítače umožňují zárověň vizuálně zobrazit aktivované části klávesnice či myši. Většina parametrických modelářů umožňuje efektivní práci právě s využitím klávesových zkratek, jejich aplikování $\mathrm{v}$ přednáškách však považuji $\mathrm{z}$ uvedeného důvodu za převážně nevhodné. Opak lze očekávat od multimediálního výukového materiálu. Pro realizaci multimediálního učení dle Dostála (2009) není podstatné, zda do jeho procesu vstupují integrovaná multimédia nebo jednotlivé pomůcky $\mathrm{v}$ různém formátu, které umožňují prezentovat informace. Podstatné je, že tyto působí na více smyslů osoby vzdělávaného současně. Multimedální materiály jsou prostředky tzv. vzdělávání podporovaného technologiemi (technology-based training), které představují poskytování informací, školících materiálů a vzdělávacího obsahu prostřednictvím různých forem elektronických médií; je součástí e-learningu. $Z$ tabulky 1 vyplývá, že méně než polovina vysokoškolských pedagogů aplikuje prvky e-learningu v rámci prezenční výuky. Bližší popis výsledků šetření je dostupný v literatuře Alternativní technologie pro tvorbu multimediálních opor výuky

Adobe Captivate je možným nástrojem pro tvorbu interaktivních multimediálních výukových prostř̌edků a simulací běhu a ovládání různých softwarových aplikací. Během práce $\mathrm{v}$ prostředí parametrického modeláŕe jsou ukládány obraz jeho pracovní plochy i události pocházející z klávesnice a myši. $\mathrm{V}$ editačním režimu pak lze záznam obrazu pracovní plochy rozšiřiit o hlasové komentáře, textové popisy, rastrové obrazy $\mathrm{v}$ různých datových formátech, audiovizuální sekvence ve formátu Microsoft AVI (audio video interleave), jednoduchou vektorovou grafiku, prezentace Microsoft PowerPoint a př́padně některé interaktivní prvky (tlačítka, odkazy apod.). Výsledné dílo lze uložit $\mathrm{v}$ podobě samospustitelné aplikace (Windows executable),
Microsoft AVI nebo souboru ve formátu podporovaným Macromedia Flash (SWF, FLA, FLV). Lze jej sdílet prostřednictvím webového rozhraní či FTP (file transfer protocol) serveru. Předností této varianty jsou minimální nároky na znalosti uživatele $\mathrm{v}$ oblastech počítačové grafiky, multimédií či programování.Snímáním obrazu pracovní plochy počítače lze prostř̌ednictvím jiných softwarových nástrojů (např. TechSmith SnagIt, Hyperionics Technology LLC HyperCam apod.) tvořit komprimované vizuální sekvence ve formátu Microsoft AVI bez vysokých nároků na volný datový prostor pevného disku. Zvukový komentár̆ lze ukládat souběžně či nezávisle. Kvalita zvukového záznamu je samozřejmě závislá na použité zvukové kartě a externím mikrofonu. Vlastní pracoviště, na kterém je audiozáznam tvořen, by mělo být dle Zatloukala [2005] vhodně akusticky přizpůsobeno, protože různé hluky a ruchy působí ve zvukovém záznamu negativně a mohou znehodnotit celé výsledné dílo.. Záznam obrazu a zvuku lze synchronizovat prostřednictvím nástroje pro zpracování audiovizuálních materiálů např̀. některého ze skupin produktů Adobe Premiere, Sony Vegas či Canopus Edius. S využitím značného množství audio a video stop lze realizovat střih záznamu, modifikovat rychlost reprodukce jeho jednotlivých částí, aplikovat různé přechodové efekty či filtry, vložit titulky apod. Strukturu prŕípadného budoucího optického média, časové osy, playlisty, kapitoly, i vícejazyčné titulkové sady, grafické návrhy apod. lze realizovat prostřednictvím uvedených aplikací či sofistikovaných nástrojů, jako jsou např. Adobe Encore či Sony DVD architekt. Pro komprimování výsledného záznamu je nezbytné použít snadno dostupný kodek, např. některý ze skupiny MPEG (Motion pictures experts group).

\section{Závěr}

V literatuře je uvedeno, že člověk údajně disponuje výrazně kreativní schopností vizuálního myšlení, myslí ne slovy, ale prostřednictvím vizuálních představ. Zrakové myšlení nachází uplatnění zejména $\mathrm{v}$ abstraktních disciplínách. Vnímání vizuálních informací představuje největší podíl z celkového vnímání všemi smysly. Vizuální předvedení upoutává pozornost, vzbuzuje zájem a napomáhá konceptualizaci. Výklad spojený s praktickou ukázkou je účinným. Mnoha pojmům a myšlenkám lze porozumět spíše vizuálně než verbálně, např. praktickým dovednostem. sloužit především k rozšiřrení obrazového vjemu. Proto je 
při tvorbě multimediální výukové aplikace třeba dbát, aby hlasový komentár zprostředkoval pouze informace, které $z$ videozáznamu jednoznačně nevyplývají. Bez ohledu na libovolnou aplikovanou technologii je zřejmé, že tvorba multimediálních opor výuky nejen parametrického modelování je $\mathrm{v}$ možnostech i jediného pedagoga a mohla by jim být věnována ještě větší pozornost.

Článek byl vytvořen $\mathrm{v}$ rámci projektu Specifického výzkumu na UHK Hradec Králové číslo SV 2011

\section{Literatura}

[1] DOSTÁL, Jiří. Multimediální, hypertextové a hypermediální učební pomůcky - trend soudobého vzdělávání. Časopis pro technickou a informační výchovu, 2009, č. 3, s. 18 - 23. ISSN 1803-537X.

[2] FOŘT, Petr; KLETEČKA, Jaroslav. Autodesk Inventor - Funkčni navrhováni v prümyslové praxi. Brno: Computer Press, 2007. 318 s. ISBN 978-80-251-1773-6.

[3] HuBÁlovskÝ, Š.-ŠEDIVÝ J. Didaktické aspekty analýzy dat In: Media4u Magazine. no. X1 (2010), , ISSN 1214-9187.

[4] LINHART, Josef. Psychologie učeni: Př́ručka pro studium na pedagogických fakultách. Praha: Státní pedagogické nakladatelství, 1967. $392 \mathrm{~s}$.

[5] MELEZINEK, Adolf. Inženýrská pedagogika. Praha: České vysoké učení technické v Praze, 1991. 140 s. ISBN 80-01-00672-4.
[6] PETTY, Geoffrey. Moderní vyučování. Praha: Portál, 1996. 380 s. ISBN 80-7178-070-7.

[7] SEDLÁČEK, Jan. Zkušenosti s využitím systému Mediasite na Fakultě informatiky a managementu Univerzity Hradec Králové [online]. 2007 [cit. 2010-02-12]. Dostupný z WWW:

http://everest.natur.cuni.cz/konference/

2007/prispevek/ sedlacek.pdf >.

[8] ZATLOUKAL, Karel. Spolupráce v oblasti multimediální tvorby. In Sborník príspěvků ze semináre a soutěže eLearning 2005, Hradec Králové, 8. - 11. 11. 2005. Hradec Králové: Gaudeamus, 2005, s. 386 - 389, ISBN 80-7041-595-9.

[9] ZLÁMALOVÁ, Helena. E-learning a hodnoceni kvality [online]. 2007 [cit. 2010-0212]. Dostupný z WWW: < http://everest.natur.cuni.cz/ konference/2007/ prispevek/zlamalova.pdf $>$.

\section{Mgr. Josef Matějus \\ Stř̌ední škola aplikované kybernetiky, Hradecká 1151, 50003 Hradec Králové matejus@ssakhk.cz}

Ing. Josef Šedivý, PhD.

Př́rodovědecká fakulta UHK

Katedra informatiky

Náměstí Svobody 301

50003 Hradec Králové

e-mail: josef.sedivy@uhk.cz 